\title{
Foreign Direct Investment and Manufacturing Growth: The Case of Tax Incentives in Puerto Rico
}

\author{
Wilfredo Toledo \\ University of Puerto Rico, San Juan, Puerto Rico \\ Email: wilfredotoledo@aol.com
}

How to cite this paper: Toledo, W. (2017) Foreign Direct Investment and Manufacturing Growth: The Case of Tax Incentives in Puerto Rico. Modern Economy, 8, 272281.

https://doi.org/10.4236/me.2017.82019

Received: January 2, 2017

Accepted: February 21, 2017

Published: February 24, 2017

Copyright $\odot 2017$ by author and Scientific Research Publishing Inc. This work is licensed under the Creative Commons Attribution International License (CC BY 4.0).

http://creativecommons.org/licenses/by/4.0/ (c) (i) Open Access

\begin{abstract}
The aim of this paper was to determine the effects that the end of tax incentive for U.S. firms operating in Puerto Rico had on the growth trend of the manufacturing sector in the island. It was found evidence that the termination of these incentives diminished manufacturing employment growth trend. This reduction was transmitted to Puerto Rico's aggregate real output. Real GNP declined at an average rate of $1.7 \%$ per year from 2007 to 2015 . Thus, it may be argued that foreign capital may stimulate economic growth in the short run, but that increase may be artificial without local means to be maintained in the long run.
\end{abstract}

\section{Keywords}

FDI, Tax Incentives, Manufacturing, Structural Changes, Andrew-Quandt Test

\section{Introduction}

There is an extensive literature on the determinants of foreign direct investment (FDI). According to Mundell [1] differences in factor endowments across countries are an important determinant of international capital flows. Also, the costs associated with the movement of the merchandise between countries and trade barriers affect the levels of FDI (Williamson [2] and Brainard [3]). Others factors that have been found to be important in explaining the international movements of capital to a specific country are: the exchange rate, the social institutions, the stability of the political system, the cost of doing business, taxes, and infrastructure (Dunning [4], Grubert \& Mutti [5], Lipsey [6], Resmini [7], Wheeler and Mody [8]), Schneider and Frey [9], Cheng and Kwan [10], Lucas [11], and Gastanaga \& Pashamova [12]). Different countries usually utilize dif- 
ferent combinations of these incentives to try to attract the flow investment for their economies, because there is evidence that these flows seem to promote economic growth (Duasa [13], Gorge and Greenaway [14], Hanson [15], Griffith, Waithe and Craigwell [16], Rahman [17] and Rodríguez-Clare [18]).

However, recent papers have pointed out that some flows of external funds may have negative effects on some countries in the long run. For example, Blanchard and others [19] find that capital inflows may lead to currency appreciation and negative effects on exportations of host economies. Along the same lines, Ghosh, et al. [20] find evidence that certain types of capital flows can generate a financial crisis in some countries. Both studies use data from emerging market economies. On the other hand, it is known that manufacturing sector is one of the sectors that receive high-levels of FDI flows. Thus, it is interesting to study if that type of funds promotes the long-run development of this sector in less developed countries, transferring new technologies, for example, or if they create dependence that can lead to serious recessions when capital leaves the host economy.

This paper examines the special case of Puerto Rico. This Caribbean island has a political relationship with the United States of America. U.S. has control over international trade and customs administration in Puerto Rico, and there is free movement of people and merchandise between both countries. Also, the currency of the island is the United States dollar. In economics terms, it can be thought, in a lax way, of Puerto Rico as a region of U.S.

In 1976 the United States established tax incentives to U.S. companies operating in Puerto Rico, to promote economic growth in the island. It was allowed that subsidiaries of U.S. corporations that were operating on the island could send back their profits to the parent company without paying federal taxes. These incentives (Section 936 of U.S. Tax Code) ended in 1996 for new businesses, with a phase-out period of 10-year for existing firms.

These tax incentives were effective in promoting a considerable growth of Puerto Rico economy through manufacturing. This sector was the key driver of job creation of Puerto Rico's economy for several decades which have shown steady labor productivity and exports growth. However, this growth was based upon tax incentives not controlled by P.R., but by the United States. Once it was ended, the manufacturing sector in the Island reduced its size almost in half. The establishment of North American Free Trade Agreement (NAFTA) of 1994 , and the Central America Free Trade Agreement (CAFTA) of 2004 increases the attractiveness of others countries, relative to Puerto Rico, as hosts of the United States foreign directs investment, and is an additional potential factor responsible for the manufacturing decline in the island. Table 1 shows the net inflows of FDI to the island from 2006 to 2015. As is evident, this variable has been negative since 2012.

The objective of this paper is to determine the effects of the end of tax incentive or U.S. firms operating in Puerto Rico had on the growth trend of the manufacturing sector in the island. This is an interesting case to examine for various reasons. Though the American companies also receive tax exception under 
Table 1. Foreign direct investment, net inflows to Puerto Rico (Millions of US dollars).

\begin{tabular}{lc}
\hline Year & Net inflow \\
\hline 2006 & 1326.3 \\
2007 & 1539.4 \\
2008 & 9391.9 \\
2009 & 5563.2 \\
2010 & 2816.3 \\
2011 & 5177.2 \\
2012 & -4047.3 \\
2013 & -9368.0 \\
2014 & -8621.1 \\
2015 & -4722.2 \\
\hline
\end{tabular}

Puerto Rico's laws, the principal benefit of doing business in the island was the tax exception to profits transferred to matrix companies in the United States. This represented considerable advantages for such industries. These are capitalintensive companies with high productivity level, but their production depends on the right over patents that local firms cannot reproduce. Thus they stimulated the local service sector, but not others manufacturing firms. Also, it can be hypothesized that knowledge transfer may be in the management process, but not in the production process itself, because of the property rights associate to the patents. Hence, it has the statement that the principal benefits of the FDI seem to be transitory, while the firms are producing in the conjecture in this example. Therefore, Puerto Rico is an extreme case of the effects of foreign capital on the economic growth of developing countries, and the results of the analysis are useful for the design of economic development policies related to the attraction of international capital.

The achievement of the objective of this research confronts at least two limitations. First, because there is free trade between these two countries, there is no high-frequency data about the FDI movement from the mainland to the island. Second, there is no high-frequency data of manufacturing production. To overcome the first difficulty, an indirect method was used to examine the issue posed. In this analysis, it was identified the performance of manufacturing sector, and some of its subsector, before and after the change in the incentive laws. The study uses descriptive statistics, and Andrew-Quant methods, to determine the structural change dates in the trend of growth of manufacturing employment. Monthly employment series of this sector was used as the indicator of the state of this sector, for these analyses. This data is available from 1990 to $2013^{1}$.

\section{Methods}

To analyze the impact of the termination of the tax incentive programs on the

${ }^{1}$ This is the longest period for which exists consistent data of Puerto Rico sectoral employment. 
trend of the manufacturing employment series, the following general model was used:

$$
L_{t}=\beta_{0}+\beta_{1} t+\sum_{i=1}^{m} \beta_{2 i} d_{i t}+\sum_{i=1}^{m} \beta_{3 i} d_{i t} t+\varepsilon_{t}
$$

where: $L_{t}$ is the employment series; $t$ is a trend variable; $m$ indicates the number of regimes; the $d_{i t}$, for $i=1,2, \cdots, m$, are dummy variables that assume the value of one in periods of regime $i$ and zero in the other periods, and $\varepsilon$ is a stochastic element. This equation allows for multiple breaks in the growth trend of the manufacturing sector employment. The challenge is to associate these breaks with the end of tax incentives to the firms in this economic sector.

It will be necessary, however, to identify first, in an objective way the dates of the structural changes that have affected the variables of interest. There are different methods to detect breaks in time series, but the standard test was developed by Chow [21]. This test is based on the consideration of a linear regression model that can be represented as:

$$
Y_{t}=X_{t} \beta+\varepsilon_{t}, \varepsilon \sim N\left(0, \sigma^{2}\right), \forall t \leq T
$$

where: $Y_{t}$ is the dependent variable; $X_{t}$ is the matrix $(k \times T)$ of explanatory; $\epsilon_{t}$ is a stochastic element and $\beta$ is a vector, $k \times 1$, that contains the parameters of the model.

Model (2) implies that the relation between $Y$ and the $X$ s's have been constant through time. However, the economic system is subject to random shocks continuously causing changes in the parameter that define the relationship between these variables, thus is not correct to assume that $\beta^{\prime} \mathrm{s}$ is fixed. For example, in the case that observations $(T)$ fall into two different parameter regimes $\left(t_{1}\right.$ and $\left.t_{2}\right)$ they can be split into two groups of $t_{1}+t_{2}=T$ and model (2) may be written as;

$$
\begin{aligned}
& Y_{t}=X_{t} \beta_{1}+\varepsilon_{t 1}, \quad \forall t \leq t_{1} \\
& Y_{t}=X_{t} \beta_{2}+\varepsilon_{t, 2}, \quad \forall t>t_{1}
\end{aligned}
$$

In Chow-test of structural break, applied to (3), the following hypotheses are tested:

$$
\begin{aligned}
& H_{0}: \beta_{1}=\beta_{2} \\
& H_{a}: \beta_{1} \neq \beta_{2}
\end{aligned}
$$

The null hypothesis imposes the restriction that parameters are fixed through time (model (2) is correct). Under normality assumptions the ratio:

$$
F_{C}=\frac{\hat{\varepsilon}^{\prime} \hat{\varepsilon}-\left(\hat{\varepsilon}_{t 1}^{\prime} \hat{\varepsilon}_{t 1}+\hat{\varepsilon}_{t 2}^{\prime} \hat{\varepsilon}_{t 2}\right) / k}{\left(\hat{\varepsilon}_{t 1}^{\prime} \hat{\varepsilon}_{t 1}+\hat{\varepsilon}_{t 2}^{\prime} \hat{\varepsilon}_{t 2}\right) / T-2 k} \sim F(k, T-2 k)
$$

One limitation of this test, as Hansen [22] points out, is that the date of the structural change must be known in advance. Quandt [23] proposed to compute the Chow statistic $\left(F_{c}\right)$ over all possible $t_{1}$ and take the break/date as the period with the highest value of this statistics. Andrews [24] developed several statistics to test the structural break hypothesis. He examined a model indexed by the parameters $\left[\beta_{t} \psi_{0}\right]$ and formulated the following hypothesis of parameters sta- 
bility over time:

$$
H_{0}=\beta_{t}=\beta_{0} \quad \forall t \geq 1 \quad \text { para } \beta_{0} \in B \subset R^{P}
$$

An option for the alternative hypothesis is:

$$
\begin{aligned}
& H_{A}(\pi): \beta_{t}= \begin{cases}\beta 1(\pi) & \text { para } t=1, \cdots, T \pi \\
\beta 2(\pi) & \text { para } t=T \pi+1\end{cases} \\
& \operatorname{para} B_{1}(\pi), B_{2}(\pi) \in B \subset R^{P}
\end{aligned}
$$

where: $\pi \in(0,1)$

In case that $\pi$ is known the standard Chow statistics can be used with the $F$ or chi-square distribution, as was discussed above. Nevertheless, when $\pi$ is unknown, the usual parametric distribution is not valid, because the parameter $\pi$ appears under the alternative hypothesis but does not under the null. Andrews derives the asymptotic distribution of the following statistics:

$$
\sup _{\pi \in \Pi} W_{T}(\pi) \underset{\pi \in \Pi}{L} L M_{T}(\pi) \quad y \quad \underset{\pi \in \Pi}{L R_{T}}(\pi) \quad \pi \in(0,1) .
$$

where: sup is the upper value of all the statistics calculated in the time interval. The author presents a Table with the critical values for the test.

This procedure was applied to some of the Puerto Rico's manufacturing employment series. A linear trend model was used for this purpose. The method developed by Bai [25] was utilized to construct $95 \%$ intervals for the dates of the structural changes. Furthermore Granger causality tests were performed to determine the impact of manufacturing employment on total employment in the island. Eviews software was utilized for all the estimations.

As it was mentioned above, the following potential sources of structural change that impacted the manufacturing sector in the island in the period of analysis may be identified: the reduction of USA tax incentives to corporations of that country doing business in Puerto Rico (1996 for new firms and 2006 for the those established already in P.R.), the establishment of free trade agreements of U.S with other countries of in the region (NAFTA in1994 and CAFTA in 2004).

\section{Empirical Results}

In this section, the dynamics of Puerto Rico manufacturing employment, from 1990 to 2013 is analyzed. This is the period for which there is industrial level data with the North American Industrial Codes System (NAICS) the new codification used in the island.

When the growth rate in employment of manufacturing sectors is analyzed we reach the conclusion that from 1996 to 2006 only the Pharmaceutical sub- sector shows a positive average growth, as it is evident in Table 1. All the remaining industries had negative growth trends during those ten years. However, from 2007 to 2013 the level of employment in all sectors decreased. The sub- sectors, also, show a large volatility of their employment growth rate, judging by the coefficient of variation. This may be the result of external shocks that affected the whole manufacturing sector. 
The estimated dates of the structural changes in the growth trend of five series of employment in the manufacturing sector in Puerto Rico are presented in $\mathrm{Ta}$ ble $2^{2}$. Also, a 95 percent interval for the estimation is reported in the table. The break in the trend of the series was estimated allowing for a shift in the intercept together with a change in the slope coefficient: the case of a pure structural change. The principal finding of this analysis is that the growth rate of the total manufacturing employment shows a large shift, in June of 1996. As a consequence of this change, the rate of growth of that variable was reduced. This series also has additional breaks in the growth trend in 2001:07 and 2003:1. For the case of the total manufacturing employment the following model shows the effects of these structural changes over its growth path:

$$
L_{M N F}=217.4-0.41 t-0.004 d_{1996: 06} \times t-3.74 d_{2001: 07}+0.004 d_{2003: 11} \times t+e
$$

$R^{2}=0.99$ (all parameter estimates are significant at 0.001 level)

$Q(4)=2.7$. P-Value of 0.44

where: $L_{M N F}$ is the total employment in manufacturing; $t$ is the trend variable; and $d_{Y: X}$ is a dummy variable equal to one after month $X$ of year $Y$ and zero otherwise, and e is the error term:

As can be seen from the estimation results the model adjusts well the data. The diagnostic checking of the model shows high determination coefficient, significant estimated parameters and white noise residuals. This finding is broadly in line with the conjecture that the reduction of the USA's incentives to manufacturing companies doing business in Puerto Rico is the principal cause of the melt down of this sector's activity. In fact, the structural changes in 1996 have the larger LR-statistics meaning that it was the most important break of the series trend.

The application of the Andrews/Quandt structural break identification procedures can be summarized as follows: three structural breaks were identified in each of the growth trends of the five employment series examined, as is evident in Table 3. The total manufacturing's employment series had the first break in June of 1996. The effect of this structural change was an increase in the reduction

Table 2. Descriptive statistics of manufacturing employment growth rate by sub-sectors (monthly data).

\begin{tabular}{ccccc}
\hline & \multicolumn{2}{c}{$1996: 012006: 12$} & \multicolumn{2}{c}{$2007: 012013: 03$} \\
\cline { 2 - 5 } & $\begin{array}{c}\text { Mean } \\
\text { (in percent) }\end{array}$ & $\begin{array}{c}\text { Coefficient of } \\
\text { Variation } \\
\text { (absolute value) }\end{array}$ & $\begin{array}{c}\text { Mean } \\
\text { (in percent) }\end{array}$ & $\begin{array}{c}\text { Coefficient of } \\
\text { Variation } \\
\text { (absolute value) }\end{array}$ \\
\hline Sub-sector & & $3.32 \%$ & -0.76 & $427.7 \%$ \\
\hline Pharmaceutical & 0.0867 & $398.3 \%$ & -0.55 & $938.8 \%$ \\
Clothing & -0.982 & $762.2 \%$ & -0.15 & $1092.4 \%$ \\
Food & -0.365 & $780.0 \%$ & -0.96 & $216.0 \%$ \\
Computers and & -0.364 & & & \\
\hline electronic & & & & \\
\hline
\end{tabular}

${ }^{2}$ It was found that the employment series are $\mathrm{I}(0)$. 
Table 3. Test statistics, break points, and confidence intervals for the trends models of employment (Selected employment Series).

\begin{tabular}{|c|c|c|c|c|}
\hline Industry & $\begin{array}{c}\text { Date of } \\
\text { Break }\end{array}$ & LR Statistic & P-value & $95 \%$ interval \\
\hline \multicolumn{5}{|c|}{ Manufacturing } \\
\hline & 2003:01 & 54.23 & 0.0000 & {$[2003: 10,2003: 12]$} \\
\hline & 2001:07 & 90.76 & 0.0000 & [2001:06, 2001:08] \\
\hline & 1996:06 & 415.48 & 0.0000 & {$[1996: 05,1996: 07]$} \\
\hline \multicolumn{5}{|c|}{ High technology industries* } \\
\hline & 2009:03 & 145.45 & 0.0000 & {$[2009: 02,2009: 04]$} \\
\hline & 2005:01 & 601.82 & 0.0000 & {$[2004: 12,2005: 02]$} \\
\hline & 1995:02 & 394.42 & 0.0000 & {$[1995: 01,1995: 03]$} \\
\hline \multicolumn{5}{|c|}{ Medicines } \\
\hline & 2009:01 & 59.36 & 0.0000 & {$[2008: 11,2009: 03]$} \\
\hline & 2004:08 & 1338.45 & 0.0000 & {$[2004: 07,2004: 09]$} \\
\hline & 1996:10 & 138.92 & 0.0000 & {$[1996: 08,1996: 12]$} \\
\hline \multicolumn{5}{|c|}{ Clothing } \\
\hline & 2011:08 & 41.37 & 0.0000 & {$[2011: 05,2011: 11]$} \\
\hline & 2002:07 & 963.99 & 0.0000 & {$[2002: 06,2002: 08]$} \\
\hline & 1993:10 & 84.89 & 0.0000 & {$[1993: 08,1993: 12]$} \\
\hline \multicolumn{5}{|c|}{ Food } \\
\hline & 2008:12 & 130.2898 & 0.0000 & [2008:09 2009:03] \\
\hline & 2001:06 & 271.07 & 0.0000 & {$[2001: 04,2001: 08]$} \\
\hline & 1995:01 & 81.53 & 0.0000 & [1994:11, 1995:3] \\
\hline
\end{tabular}

Monthly data from 1991:01-2013; 04, SA. *Defined as the sum of employment in: chemical, computers and electronic, electrical equipment, and medical devices industries.

rate of this series. This change in the path of manufacturing employment may be related to the end of the 936 section of the Federal Tax Code, and the beginning of NAFTA.

On the other hand, the employment for the industries with high-level technological production processes (High-Tech.) shows a shift, in 1995:02. This break switches the slope of this variable's trend from positive to negative. The other two structural changes that affected this series occurred in the years 2005 and 2009. The first shifts increased the rate of reduction of this variable while the second one reduced it. A visual examination of the behavior of the High-Tech.'s industry growth path suggests that this series is moving toward a stationary state.

Testing for structural changes on monthly data for the pharmaceutical employment series gives three breaks dates: in October of 1996, in August 2004 and in January 2009. The Bai 95 percent confidence interval for the first break/date is [1996:08, 1996:12], which is fairly tight. The 95 percent confidence intervals for the other two break/dates are [2004:07, 2004:09] and [2008:11, 2009:03] respectively.

The other two series, employment in the food and clothing sectors, have sig- 
nificant breaks before 1996. In the apparel sector's employment it was found in 1993:10, while in the food sector the date of the break was 1995:01. These series have a similar timing of the structural shifts in their employment in the 21 century of other sectors, as can be seen in Table 3.

The reduction in this economic sector activity impacted the whole island economy. Strong evidence was found that manufacturing employment "Ganger cause" private employment (excluding manufacturing employment) in Puerto Rico (Table 4). Also, it was estimated an elasticity of private employment with respect to manufacturing employment of 0.40 . So, on average, one percent increases (decreases) in $L_{M N F}$ increases (decrease) $L_{P R I V}$ by 0.40 percentage point, according to this estimation.

These findings support the proposition that the manufacturing sector was crucial for this country's economic growth and development. The end of U.S. tax incentive for the American firms operating in the island diminished manufacturing employment by nearly 50 percent. The result of this reduction was a decrease in Puerto Rico's real GNP from 2007 to 2015. On average aggregate real production declines in nearly $1.7 \%$ annually.

\section{Conclusions}

In conclusion, it was found in this study, using a methodology of determining structural breaks without an arbitrary partitioning of the time series that the reduction that was experiencing the manufacturing sector's employment in the island began after 1996. Thus, the end of tax incentives for U.S. corporations seems to be the principal reason for this decline. However, the reductions in the more labor-intensive manufacturing sectors happened before this year and are likely that was related to the loss of competitiveness in this type production, due to NAFTA and other globalization effects. It was also found that these shocks had permanent negative impacts on the structure of this economic sector as well as on the aggregate Puerto Rico's economic activity.

What can be learned from the case of Puerto Rico? Foreign capital may boost economic growth for a while, but that growth may be artificial without local means to be maintained. It is difficult to transfer technological knowledge if the production is based upon patented products that need a huge amount of capital

Table 4. Granger causality test: manufacturing employment and private employment.

\begin{tabular}{cccc}
\hline Lag order & Null Hypotheses & F-statistics & P-value \\
\hline \multirow{2}{*}{$1^{*}$} & $L_{M N F} \neq \gg L_{P R I V}$ & 3.97583 & 0.0472 \\
& $L_{P R I V} \neq \gg L_{M N F}$ & 1.50804 & 0.2205 \\
\multirow{2}{*}{$2^{* *}$} & $L_{M N F} \neq \gg L_{P R I V}$ & 2.65079 & 0.0725 \\
& $L_{P R I V} \neq \gg L_{M N F}$ & 0.85339 & 0.4272 \\
\multirow{2}{*}{$4^{* *}$} & $L_{M N F} \neq \gg L_{P R I V}$ & 2.36818 & 0.0532 \\
& $L_{P R I V} \neq \gg L_{M N F}$ & 3.23432 & 0.0130 \\
\hline
\end{tabular}

Optimum lag length according to: ${ }^{\star}$ Schwartz, ${ }^{* *}$ Hanna-Quinn, and ${ }^{* * *}$ Akaike, criterion. Read $\neq \gg$ as: does not Granger-cause. Note: Private Employment without $\mathrm{L}_{\mathrm{MNF}}$. 
to be reproduced. Also, if the production is based on research and development activities done outside the host country, the principal source of value cannot be transferred to the developing economy: the imported investment may create economics activity that increases the level of consumption of the host economy's agents that cannot be sustained in the long run. The economic actors may develop habits or commitment on their expenditures that cannot be satisfied when capital leaves the country.

This study had the limitation of lack of high frequency foreign direct investment data for the country analyzed. Hence additional studies of this topic using monthly or quarterly data from other countries are needed.

\section{References}

[1] Mundell, R. (1957) International Trade and Factor Mobility. The American Economic Review, 47, 321-335.

[2] Williamson, O. (1975) Markets and Hierarchies: Analysis and Antitrust Implications. Free Press, New York.

[3] Brainard, S. (1993) An Empirical Assessment of the Factor Proportions Explanation of Multinational Sales. NBER Working Paper No. 4583.

[4] Dunning, J.H. (1993) Multinational Enterprises and the Global Economy. Addison Wesley Publishing Co., Harlow, Essex.

[5] Grubert, H. and Mutti, J. (1991) Taxes, Tariffs and Transfer Pricing in Multinational Corporate Decision Making. Review of Economics and Statistics, 73, 285-293. https://doi.org/10.2307/2109519

[6] Lipsey, R.E. (2001) Foreign Direct Investment and the Operations of Multinational Firms: Concepts, History, and Data. NBER Working Paper Series Working Paper 8665. https://doi.org/10.3386/w8665

[7] Resmini, L. (2000) The Determinants of Foreign Direct Investment into the CEECs: New Evidence from Sectoral Patterns. The Economics of Transition, 8, 665-689. https://doi.org/10.1111/1468-0351.00060

[8] Wheeler, D. and Mody, A. (1992) International Investment Location Decisions: The Case of US Firms. Journal of International Economics, 33, 57-76. https://doi.org/10.1016/0022-1996(92)90050-T

[9] Schneider, F. and Frey, B. (1985) Economic and Political Determinants of Foreign Direct Investment. World Development, 13, 161-175. https://doi.org/10.1016/0305-750X(85)90002-6

[10] Cheng, L. and Kwan, Y. (2000) What Are the Determinants of the Location of Foreign Direct Investment? The Chinese Experience. Journal of International Economics, 51, 379-400. https://doi.org/10.1016/S0022-1996(99)00032-X

[11] Lucas, R. (1993) On the Determinants of Direct Foreign Investment: Evidence from East and Southeast Asia. World Development, 21, 391-406. https://doi.org/10.1016/0305-750X(93)90152-Y

[12] Gastanaga, V.J.N. and Pashamova, B. (1998) Host Country Reforms and FDI Inflows: How Much Difference Do They Make? World Development, 27, 1299-1314. https://doi.org/10.1016/S0305-750X(98)00049-7

[13] Duasa, J. (2007) Determinants of Malaysian Trade Balance: An ARDL Bound Testing Approach. Global Economic Review, 36, 89-102.

https://doi.org/10.1080/12265080701217405 
[14] Gorg, H. and Greenaway, D. (2002) Much Ado about Nothing? Do Domestic Firms Really Benefit from Foreign Direct Investment? Research Paper 2001/37, Globalisation and Labour Markets Programme, at Leverhulme Centre for Research on Globalisation and Economic Policy, Nottingham.

[15] Hanson, G.H. (2001) Should Countries Promote Foreign Direct Investment? G-24 Discussion Paper No. 9, United Nations, New York.

[16] Griffith, R., Waithe, K. and Craigwell, R. (2008) The Significance of Foreign Direct Investment to Caribbean Development. Mimeo, Ministry of Finance, Economic Affairs and Energy and the University of the West Indies, Kingston.

[17] Rahman, M. (2009) Contributions of Exports, FDI and Expatriates' Remittances to Real GDP of Bangladesh, India, Pakistan and Sri Lanka. Southwestern Economic Review, 36, 141-154.

[18] Rodriguez-Clare, A. (1996) Multinationals, Linkages and Economic Development. American Economic Review, 86, 852-873.

[19] Blanchard, O., Ostry, J.D., Ghosh, A.R. and Chamon, M. (2016) Capital Flows: Expansionary or Contractionary? American Economic Review, 106, 565-569. https://doi.org/10.1257/aer.p20161012

[20] Ghosh A.R., Ostry, J.D. and Qureshi, M.S. (2016) When Do Capital Inflow Surges End in Tears? American Economic Review. Papers \& Proceedings, 106, 581-585.

[21] Chow, G.C. (1960) Tests of Equality between Sets of Coefficients in Two Linear Regressions. Econometrica, 28, 591-605. https://doi.org/10.2307/1910133

[22] Hansen, B. (2001) The New Econometrics of Structural Change: Dating Changes in U.S. Labor Productivity. Journal of Economic Perspectives, 15, 117-128. https://doi.org/10.1257/jep.15.4.117

[23] Quandt, R. (1960) Test of the Hypothesis that a Linear Regression Obeys Two Separate Regimes. Journal of the American Statistical Association, 55, 324-330. https://doi.org/10.1080/01621459.1960.10482067

[24] Andrews, D.W.K. (1993) Tests for Parameter Instability and Structural Change with Unknown Change Point. Econometrica, 61, 821-856. https://doi.org/10.2307/2951764

[25] Bai, J. (1997) Estimation of a Change Point in Multiple Regression Models. Review of Economics and Statistics, 79, 551-563. https://doi.org/10.1162/003465397557132

\section{Submit or recommend next manuscript to SCIRP and we will provide best service for you:}

Accepting pre-submission inquiries through Email, Facebook, LinkedIn, Twitter, etc. A wide selection of journals (inclusive of 9 subjects, more than 200 journals)

Providing 24-hour high-quality service

User-friendly online submission system

Fair and swift peer-review system

Efficient typesetting and proofreading procedure

Display of the result of downloads and visits, as well as the number of cited articles

Maximum dissemination of your research work

Submit your manuscript at: http://papersubmission.scirp.org/

Or contact me@scirp.org 